Available online at: http://proceeding.rsfpress.com/index.php/pss/index

LPPM UPN “Veteran" Yogyakarta Conference Series

Proceeding on Political and Social Science (PSS)

Volume 1 Number 1 (2020): 292-300

\title{
Promotion Media Literation MSMEs Housewives Babadan Banguntapan, Kab Bantul, In Yogyakarta
}

\author{
Dewi Novianti, Siti Fatonah \\ Universitas Pembangunan Nasional Veteran Yogyakarta \\ E-mail address dewi.novianti@upnyk.ac.id; E-mail address siti.fatonah@upnyk.ac.id
}

\begin{abstract}
During the Covid-19 pandemic, many entrepreneurs went out of business; many employees had to be laid off. With the existence of the Covid-19 pandemic, everything is limited. Economic activities are increasingly uncertain. However, this is an opportunity for housewives at RW17 Babadan, Banguntapan, Bantul Regency to help the family economy. One of them is the culinary business. The first problem is that these housewives experience difficulties selling due to their limited movement to offer their culinary works to consumers. Second, the understanding of media literacy in using social media as a new media is still lacking. Third, the understanding and ability to make messages are minimal through social media. Community service methods are discussion, focused group discussion, socialization, and media literacy training. The solution to this problem is to hold training and mentoring on understanding media literacy in carrying out sales promotion activities. Also, by holding skills training in documenting culinary products and in packaging messages through social media. The conclusion is that community empowerment by providing promotional media literacy makes them understand the benefits of using modern communication tools and new media. In the end, they were able to take advantage of smartphones to sell their products.
\end{abstract}

Keywords: Promotion, new media, empowerment of housewives

\section{INTRODUCTION}

This is an open access article under the CC-BY-NC license.

Micro, Small, and Medium Enterprises (MSMEs) can support the small and medium people's economic sector. In various regions, MSMEs have been promoted in various sectors, such as culinary, agriculture, livestock, electronics, furniture, services, etc. MSMEs are divided into three types of business, namely micro, small, and medium enterprises. Referring to Law number 20 of 2008, the division between micro, small and medium enterprises is based on asset ownership and turnover. A micro business is a productive business carried out by individuals or business entities following micro criteria. When referring to the law, the micro-business criteria are a maximum of IDR 50 million in assets and a maximum IDR 300 million turnover. Next up are small businesses. This business is a productive business 
established by individuals or business entities. And not a subsidiary or branch of large companies. Small businesses have asset criteria between Rp. 50 million to Rp. Five hundred million and a turnover of around Rp. 300 million to Rp. 2.5 billion. The last is medium enterprises. This is a productive economic enterprise that is established by individuals or business entities. Not a subsidiary or branch of a large company. Medium-sized businesses have the criteria for total assets ranging from IDR 500 million to IDR 10 billion and a turnover of between IDR 2.5 billion to IDR 50 billion (Herdiyanto, 2020).

Often people look at MSMEs with one eye, but this type of business is the hope of the State of Indonesia. In 1997, there was a monetary crisis that caused many large companies to collapse. MSMEs continued to survive and even became the pillars of the economy at that time.

MSMEs in Bantul Regency is one of the economic sectors of the Bantul Regional Government which is expected to be able to improve the welfare of the people in the middle to lower classes, considering that this business has a vision that is in line with the government's program to reduce community unemployment through the opening of new jobs. Bantul Regency Government re-enumerates the number of micros, small and medium enterprises (MSMEs). From the provisional data collection results, the number of MSMEs in Bantul is around 48,000, and only 24,000 have data by name in each district. This number is less than the results of data collected by the Central Statistics Agency (BPS), which states that there are 121,000 MSMEs on Bumi Projotamansari (jogjapolitan, 2020). This large amount is an asset for the Bantul Regency Government to develop the people's economy. However, unfortunately, the spread of the coronavirus or Covid-19 has had an impact on business actors, especially Micro, Small, and Medium Enterprises (MSMEs). Many of the MSMEs experienced a decrease or even a loss. Since the Bantul Regency Governmentissued Circular Number: 440/01560 concerning the temporary closure of tourism objects to prevent the transmission of Covid-19 infection, it was continued with the extension of the closure of tourist objects from 01 to 31 April 2020 through Circular Number: 440/01615 resulting in sale transactions buying has decreased very significantly. For example, Manding Craft Center because so far, most buyers at Manding Craft Center outlets are tourists outside the region who take the time to visit to buy goods as souvenirs (Krjogja.com, 2020).

Not only at the Manding center, but other MSMEs are also feeling the impact of the Covid19 outbreak. Among them are the MSMEs PKK RW 17 Babadan, Banguntapan, Bantul. So far, the MSMEs PKK RW 17 Babadan, Banguntapan, Bantul are considered sufficient to help the family economy. The business they are doing is in the culinary field. The types of culinary produced include pastries, angkringan, meatball tofu, various snacks and snacks, rice boxes, Basreng, Kriwil Chicken, Es Susu Coki, and Peyek Kentang, Teri, Spinach, dry tempeh, and tempe kremes. Quite a variety of businesses that are produced by MSMEs PKK RW 17 Babadan, Banguntapan, Bantul. Their turnover is still very small, as seen in the following table: 
Table 1. Types of Business and MSME Turnover Women PKK RW 17 Babadan, Banguntapan, Bantul

\begin{tabular}{|l|l|l|l|}
\hline NO & NAME & TYPE OF BUSINESS & $\begin{array}{l}\text { OMSET } \\
\text { MONTHLY Rp }\end{array}$ \\
\hline 1 & Nia Kurniati & Pastry & $500.000-750.000$ \\
\hline 2 & Sri Yatini & Snack And Rice Box & 500.000 \\
\hline 3 & Ainun Irvani & Angkringan & 900.000 \\
\hline 4 & Noormawati & Meatball tofu & 10.000 .000 (bruto) \\
\hline 5 & Zuni Nuryanto & Snack, Rice Box, Various Snacks & 2.000 .000 \\
\hline 6 & Astuti Widayani & Snacks Market & 1.200 .000 \\
\hline 7 & Karniyatun & Food stalls & 1.000 .000 \\
\hline 8 & Atik Daniswari & $\begin{array}{l}\text { Basreng, Kriwil Chicken, Coki } \\
\text { Milk Ice, Dried Peanuts }\end{array}$ & 750.000 \\
\hline 9 & Gunadi & $\begin{array}{l}\text { Peanut Peyek, Anchovies, } \\
\text { Soybeans, Spinach, Green Beans }\end{array}$ & 400.000 \\
\hline 10 & Sri Hatun & Catfish Pecel & 800.000 \\
\hline 11 & Dwiriwanti & Snack Box N Catering Tk & $1.000 .000-$ \\
& & & 1.500 .000 \\
\hline
\end{tabular}

Source: MSMEs PKK RW 17 Babadan, Banguntapan, Bantul, 2020

The small monthly turnover is due to the lack of incessant marketing or promotional communication activities carried out. The PKK ladies are just waiting for the ball. Also, their marketing coverage area is very narrow only around where they live. These MSMEs are still traditional in promoting their business results. Especially after the Covid-19 outbreak emerged, sales continued to decline. Limitations of MSMEs PKK RW 17 Babadan, Banguntapan, Bantul in marketing this product due to their lack of knowledge about digital promotional media currently rife. There are various promotional media, including conventional mass media such as magazines, newspapers, tabloids, radio, and television. Media promotion with mass media requires a lot of money. In today's digital era, media promotion is getting easier. Just by using social media individually, PKK women who do MSMEs can carry out sales promotion activities. Even if they are already literate in digital media, they can efficiently market their culinary products even during the Covid-19 outbreak.

Digital media literacy is not only for teenagers, students, or housewives who monitor children and their families in interacting with the media. MSME players also need digital media literacy. Digital media literacy here means to help MSMEs PKK RW 17 Babadan, Banguntapan, Bantul in promoting their business products so that their market area becomes even broader and more accessible. Various promotional media can be used, such as FaceBook, social media, Instagram, Line, WhatsApp, and youtube. Hopefully, it can help increase the productivity of PKK RW 17 Babadan women, Banguntapan, Bantul. Muara, in the end, is to help improve family welfare. 
The economic condition of the women of PKK RW 17 Babadan, Banguntapan, Bantul, which tends to be low, is very vulnerable to various social problems. This condition also has an impact on the quality of the environment and public health. MSMEs PKK RW 17 Babadan, Banguntapan, Bantul is located in Babadan village, Banguntapan Bantul. When the earthquake occurred at the time of the earthquake on 27 July 2006, this area was among the most severely affected, which resulted in a slowdown in economic and educational development. Currently, the Covid-19 outbreak is sweeping the world, including Indonesia and especially Bantul. Since the Bantul Regency Government-issued Circular Number: $440 / 01560$ concerning the temporary closure of tourism objects to prevent the transmission of Covid-19 infection, it was continued with the extension of the closure of tourist objects from 01 to 31 April 2020 through Circular Number: 440/01615 resulting in sale transactions buying has decreased very significantly.

The statistics of the MSMEs PKK RW 17 Babadan, Banguntapan, Bantul are 11 people with 11 businesses, with various educational backgrounds ranging from high school, MAN, to elementary school graduates.

The majority of MSME business types for PKK RW 17 Babadan, Banguntapan, Bantul are culinary or food. As stated in the situation analysis above, the SME PKK RW 17 businesses are quite diverse; it is just that their turnover is still minimal.

Precisely, the problems faced by partners can be mapped as follows:

1. Lack of marketing or promotional communication carried out by MSMEs PKK RW 17 Babadan, Banguntapan, Bantul.

2. Ignorance of effective marketing communication media to increase business sales

3. The scope of the marketing area is still minimal, which is only around where they live.

4. Competition in culinary tourism is currently very high, so knowledge of marketing communication using digital media is needed

5. The world is being hit by the Covid-19 outbreak, which has a broad impact, including the decline in the people's economy. The government and citizens' implementation of lockdown makes the space for MSMEs PKK RW 17 Babadan, Banguntapan, Bantul increasingly narrow.

The formulation of the problem is how MSMEs PKK RW 17 Babadan, Banguntapan, Bantul in promoting their products by utilizing social media.

\section{LITERATURE REVIEW}

Improvement in the quality of life is always needed, especially in the economic field. Empowerment of women as family economic helpers is a common practice in society. Community empowerment is a planned social change strategy aimed at overcoming problems or meeting community needs. In the empowerment process, the community gets lessons so that they can independently make efforts to improve the quality of their life. Thus, the process must be carried out with the community's full involvement gradually, continuously, and sustainably (Wildan \& Sumarno, 2015). 
According to Jim Ife, the meaning of empowerment means providing resources, opportunities, knowledge, and skills to citizens to increase their ability to determine their future and participate in and influence the lives of their communities (Jim Ife, 1995: 182). In this community service activity, economic empowerment is carried out by providing understanding and skills in utilizing and packaging promotional messages so that the community, especially RW Babadan, a housewife. Communication is the process of delivering messages from communicators to communicants. In this process, there are elements of communication, namely: communicators, messages, communicating media, and the impact of communication. The variety of media today makes people have to be good at choosing the right media and interesting messages so that the communicators' goals are achieved. This means that communication can run effectively. One of the media that is currently booming is new media. According to Denis McQuail in his book Mass Communication Theory (2011: 43), the main characteristics of new media are their interconnectedness, their access to individual audiences as message recipients and senders, their interactivity, various uses as open characters, and their nature. -were or not depending on the location.

This media is used by the housewives of RW17 Babadan Banguntapan Bantul in promoting their business products. Rapid and innovative advances in participative Internet communications, referred to as "social media," offer modifying health behavior opportunities. Social media let users choose to be either anonymous or identified. People of all demographics are adopting these technologies, whether on their computers or through mobile devices, and they are increasingly using these social media for health-related issues (Korda \& Itani, 2013). The emergence of Internet-based social media has made it possible for one person to communicate with hundreds or even thousands of other people about products and the companies that provide them. Thus, the impact of consumer-to-consumer communications has been greatly magnified in the marketplace. This article argues that social media is a hybrid element of the promotion mix because, in a traditional sense, it enables companies to talk to their customers.

In contrast, in a nontraditional sense, it enables customers to talk directly to one another. The content, timing, and frequency of the social media-based conversations occurring between consumers are outside managers' direct control. This stands in contrast to the traditional integrated marketing communications paradigm whereby a high degree of control is present. Therefore, managers must learn to shape consumer discussions that are consistent with the organization's mission and performance goals. Methods by which this can be accomplished are delineated herein. They include providing consumers with networking platforms and using blogs, social media tools, and promotional tools to engage customers (Mangold \& Faulds, 2009). 


\section{RESEARCH METHODOLOGY}

The method used in community service adopts qualitative research in obtaining data. This method can help you get accurate data results because it prioritizes interaction, communication, and perception. As in qualitative research, according to Sugiyono (2014: 216), it concludes that qualitative research is research that is used to examine the condition of an object that is natural (as opposed to an experiment) where the researcher is the key instrument, the data collection technique is done by triangulating data, data analysis is inductive, and the research results emphasize meaning rather than generalization. How to obtain data in this community service activity begins with conducting in-depth discussions and interviews with partner managers and several housewives at RW 17 Babadan, Banguntapan Bantul. Furthermore, using the FGD model or Focus Group Discussions by inviting speakers in marketing communications and the field of motivation

\section{FINDING AND DISCUSSION}

The development of information technology in Indonesia is increasing day by day. This is greatly influenced by the ease with which people can get efficient internet facilities supported by the consumptive pattern of the community always to compete to have communication media tools. This need seems invincible with the basic needs of the majority of Indonesians. Cellular telephones, which were only owned by the middle to the upper-class economic community, can now be said that anyone can have a cellphone because the price is meager and easy to get and the ease of getting telephone access internet facilities. In the past, cellphones were only used for telephones. However, now with the development of smartphones that can be used for social media and the convenience of internet facilities, there is a shift in benefits. Smartphones are widely used for social and e-commerce media activities. This is an opportunity for MSMEs or traditional entrepreneurs to promote their products through social media.

One of the existing MSMEs is PKK RW 17 Babadan, Banguntapan, Bantul. Researchers conducted field surveys to help overcome these problems. Researchers visited the location, discussed, and conducted in-depth interviews with housewives. These housewives are MSME actors, administrators, and partner figures. The discussion results found that during the COVID-19 pandemic, the economy of the people in Plumbon Babadan Banguntapan was paralyzed. Many husbands who become laborers of Babadan residents have lost their employment relationship with their employers or have been fired. And there are husbands who used to trade or open shops were forced not to operate.

Finally, many housewives who usually sell food try to offer them through makeshift social media. Finally, it was found that the need for partners is about understanding the importance of promotional media and the importance of making promotional media messages so that the message is conveyed well. The activities carried out are holding sharing activities through the WhatsApp group about marketing communication media content through digital media. So that partners have daily experience in interacting with the media.

The next step is to conduct Focus Group Discussions by presenting resource persons in marketing communications. From the results of the FGD, it was formulated that training on how to make messages through product documentation and selection of the right message media was needed. Partner members followed this by attending to survey problems and needs with target partners. The 
findings were that many partner members were economically affected by the COVID-19 pandemic. This was of particular concern for the Team to seek opportunities by looking at the potential of MSMEs PKK RW 17 Babadan, Banguntapan, Bantul. Many housewives act as business actors to support their family's economy by producing culinary delights in food dishes. However, they still need guidance to promote

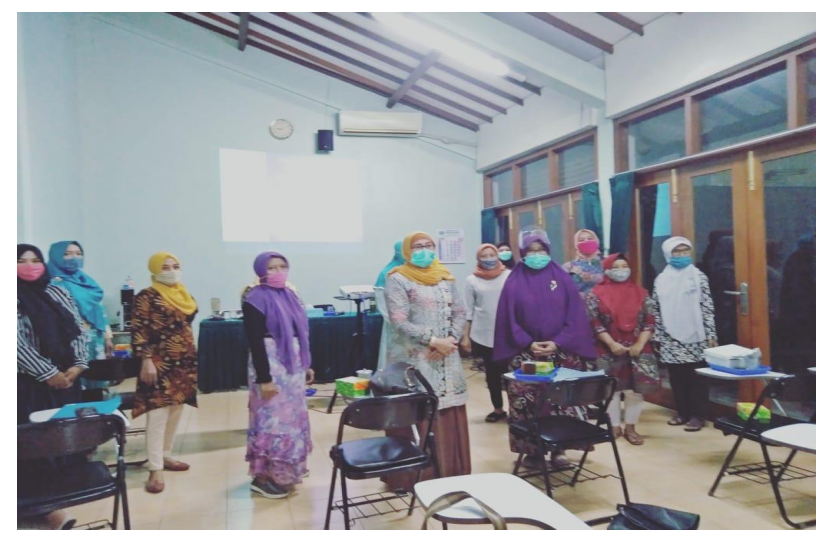

Figure 1 Promotion and socialization of media training Source: Researcher's documentation, 2020

Finally, there was a training for MSMEs PKK RW 17 Babadan, Banguntapan, Bantul, and the Trainer Team and Resource Persons. They were followed by 15 participants who are housewives who do MSMEs. Present by the Village Head and the PKK RW 17 Plumbon Banguntapan Bantul management. The training began with motivating participants to stay enthusiastic in facing the pandemic, 19. It was continued by providing understanding to partners about literacy education for marketing communication media and how to apply it to be able to apply how to use Marketing Communication media smartly. This was followed by practice, and creating sales promotion media, playing videos of successful MSME entrepreneurs using marketing communication media. The training participants all practice and send their work through the WhatsApp group and are evaluated by the Team until they can create messages and documentation through social media to promote the products being sold.

The analysis results of all Community Service activities are manifested in the form of a guidebook on media literacy and promotion for MSMEs. The hope is that the Guidebook can be used by anyone when they have a business and promote the results of that business through social media. 

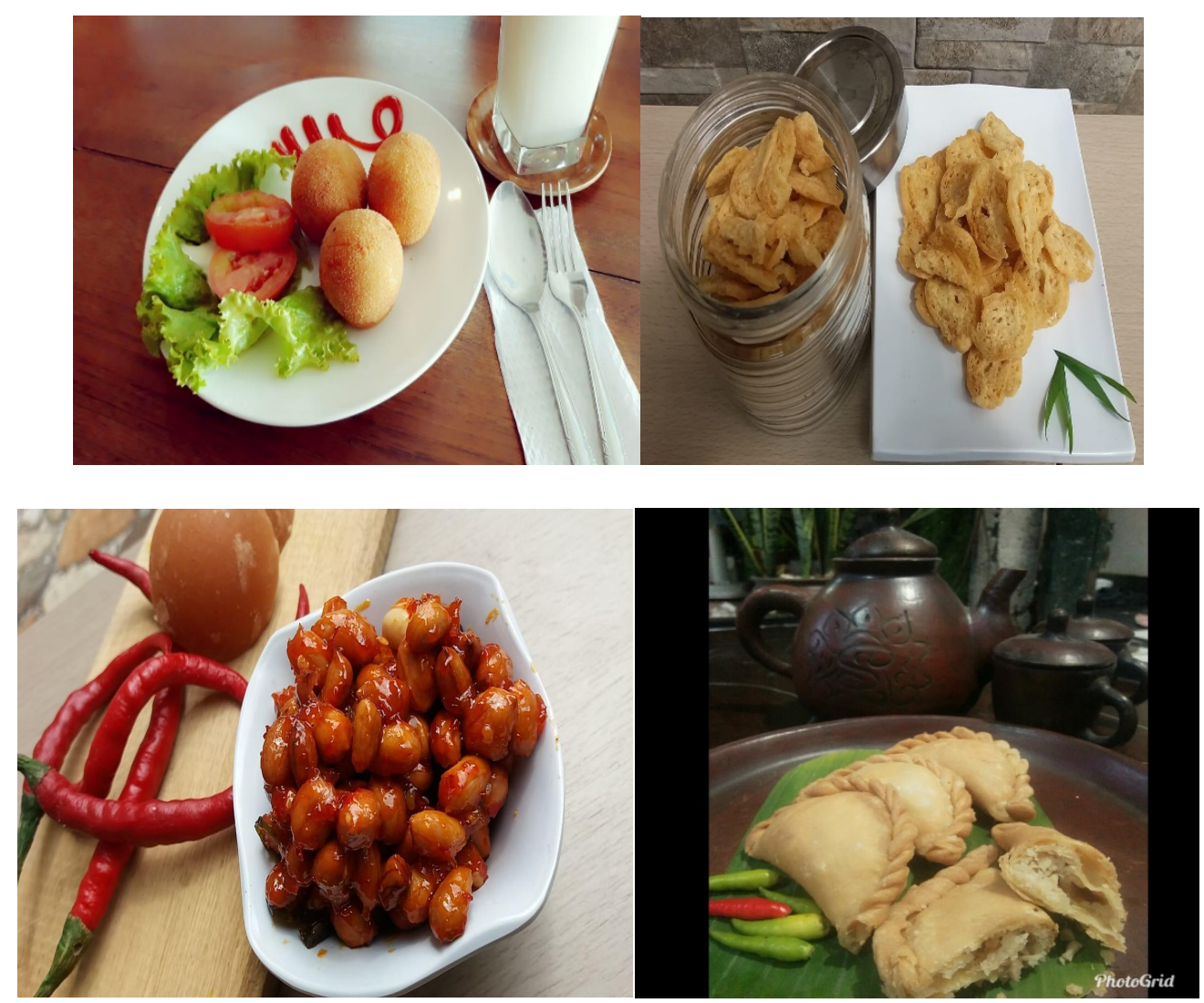

Figure 2. Results of training and mentoring

Source: Researcher's documentation, 2020

\section{CONCLUSION AND FURTHER RESEARCH}

MSMEs PKK RW 17 Babadan, Banguntapan, Bantul have high motivation to learn to use social media. It can be seen from their work after attending the training. Previously they did not understand how to make messages through social media, and now they can compose messages and choose the right media for promotion through social media. By providing promotional media literacy, empowering housewives make them understand the benefits of using modern communication tools and new media.

\section{REFERENCES}

Baran, Stanley, and Dennis K Davis. 2000. Mass communication theory. Wadsworth: Canada James, Potter W., 2005, Media Literacy, third edition. Sage Publication: New Delhi.J Ife 1995, Community Development: Creating Community Alternatives,

Vision Analysis and Practice. Australia: Longman,

Korda, H., \& Itani, Z. (2013). Harnessing Social Media for Health Promotion and Behavior Change. Health Promotion Practice, 14(1), 15-23. https://doi.org/10.1177/1524839911405850

Lister, M., Dovey, J., Giddings, S., et al. (2009). New media: a critical introduction second edition. 
New York: Routledge.

Mangold, W. G., \& Faulds, D. J. (2009). Social media: The new hybrid element of the promotion mix. Business Horizons, 52(4), 357-365. https://doi.org/10.1016/j.bushor.2009.03.002

McQuail, Denis. (2011). Teori komunikasi massa. Jakarta: Salemba Humanika.

Soemandoyo, Priyo. ND. 2010, Wacana Gender dan Layar Televisi: Studi Perempuan dalam Pemberitaan Televisi. Ford Foundation dan LP3Y: Yogyakarta.

Sugiyono. 2014. Metode Penelitian Kuantitatif, Kualitatif, dan R\&D. Bandung: Alfabeta.

Other sources:

Saugi Wildan, Sumarno Sumarno, Jurnal Pendidikan dan Pemberdayaan Masyarakat Volume 2 - Nomor 2, November 2015, (226 - 238) hal 2

http://id.wikipedia.org/wiki/Literasi media, 14/03/2015

https://qazwa.id/blog/MSMEs/Dendy Herdianto, 2020

https://jogjapolitan.harianjogja.com/read/2020/02/17/511/1032068/jumlah-MSMEs-bantulmenyusut

https://www.krjogja.com/berita-lokal/diy/bantul/diterpa-covid-19-MSMEs-di-bantulmencoba-bertahan $/ 2 /$. 